\title{
Pañchopākhyāna: Fossilized Marathi Culture and the Translation Lens
}

PRIYADA SRIDHAR PADHYE

\begin{abstract}
This paper attempts to prove that certain translations can be described as 'fossilized culture' because they reveal the culture of the times in which they were produced. Such translations have certain textual elements which are a result of the historical, political, social and translatorial context in which they were produced. In order to prove this analogy, the author has identified a Marathi translation of the Pañchatantra called Pañchopākhyāna. In order to understand what is meant by the words 'fossilized culture' in context of the translated text, a translation based textual analysis which helps in locating and situating the investigated translation in its context is undertaken. This investigation throws light on the investigated translation as well as the then prevalent activity of translation. Toury's Descriptive Translation Studies, Itamar Even-Zohar's Polysystem theory and Chritiane Nord's translation based textual analysis form the theoretical base of this paper.
\end{abstract}

Keywords: Socio-translation Studies, Time-restricted Translation Theory, Marathi Translation in the Medieval Ages, Mahāubhāvpanth, Pañchatantra.

\section{Discussion}

The "Cultural turn" in Translation Studies is a milestone, which the discipline achieved in the 1980s (Snell-Hornby: 4768). It is known to be a turn which emancipated the discipline from the field of Linguistics. We today believe that culture 
plays an indispensable role in translations, be they literary or technical.

Can one then not speak of something like 'fossilized culture'? Can a translation be considered as something in which the culture of a certain people, living in a certain time is found to be in a fossilized state? The point of departure in this paper is that some translations, though not all, in my opinion, can have the unique distinction of being described as 'fossilized culture'. In this paper an attempt is made to show how a translation can be 'fossilized culture' by undertaking the descriptive study of one such Marathi translation of the Pañchatantra. The theoretical framework is drawn from the Descriptive Translation Studies (Toury), the polysystem theory (Even-Zohar) and the translation-based text analysis model by Christiane Nord.

The paper is divided into four sections. It begins by elaborating on the analogy of translation to 'fossilized culture' mentioned in the title. The second section contains firstly, a brief introduction to those aspects of the Pañchatantra which are significant for its translations and secondly, a general overview of its spread through India and the world through the medium of translation. The focus here will be on Marathi translations of the Pañchatantra done in the Medieval Ages as the translation used for investigation in the paper belongs to the medieval period. A brief and indispensable History of the nature and development of the Marathi language, functioning as a precursor to the development of the activity of Marathi translation, is also to be found in this section. After giving this general background to the topic, the third section of the paper focuses on the analysis of an anonymous translation of the Pañchatantra titled "Pañchopakhyāna" written in the year 1776, its general description, and study of the context of the translation and an analysis thereof. This analysis will be done 
with the help of Nord's text analysis model covering text external factors like sender, intention, recipient, time, place, medium, and motive, as well as, text - internal factors such as subject matter, content, presupposition, text composition, nonverbal elements, lexis, sentence structure and suprasegmental features (Nord 1991: 43-124). Central to the deliberations on the context in which the translation has been done, will be the influences and forces which play a significant role in the shaping of the translation. In doing so, many aspects like the then prevalent socio-cultural conditions, historical context, and the location of translated literature in the literary polysystem (Even-Zohar) of the Marathi literature of the times will be elaborated upon. The concluding fourth section will summarize what the investigation has revealed to us about the investigated translation in particular and the activity of Translation in Maharashtra in the Middle Ages in general.

The questions that will be answered in this paper range from why the activity of translation was carried out in this specific period in Maharashtra, what position Translation occupied in the Marathi literary polysystem, what the translation tells about the then prevalent historical, political, social and cultural conditions which influenced its production and the function of the translation, to, what understanding of the activity of Translation in the Medieval period in Maharashtra this investigation reveals.

\section{Translation as Fossilized Culture}

My point of departure is that certain translations can be considered as 'fossilized culture'. I use the term 'fossilized' because the culture revealed to the eyes of a Translation expert through the translation, is a culture of a bygone era. Though it is generally believed that culture is dynamic, in case of translations which were done a long time ago, the adjective fossilized, which means static, unchanging, seems appropriate 


\section{Priyada Sridhar Padhye}

to describe the culture that manifests itself in the translation. What is revealed through the translation is a "snapshot" a "freeze-frame" of a culture that is no more. Just like fossils reveal a lot about life, as it existed thousands of years ago, so do such translations. They give us an insight into the landscape against which the translator did her/is work and how s/he set about achieving it. Hence the study of such translations is like connecting the dots of the cultural manifestations of the times in the text, in order to create the world in which the text is located and grounded. While reading such translations, one stumbles upon certain textual elements peculiar to the translated text. This leads to questions, which any person with an understanding of the Science of translation is bound to ask. The answers to these very questions help us in (re)creating the historical, political, sociological and cultural conditions in which the translation is situated and located.

Just as archaeology, epigraphy, study of mummies and fossils open an entire world to the eyes of an expert, research on translations done in specific periods to create an entire world in front of the eyes of a translation expert ${ }^{1}$ and thereby improve our understanding of the history and nature of the activity of translation in a particular culture at a particular time. It throws light on various aspects of Translation such as, the status, or the lack of it, enjoyed by the source text, success or failure of translations as an accepted form of literature, positioning of the translator between the source text and the target text, the nature of the act of translation as: an act of decoding the source text, creating a new text, mediating and negotiating between cultures or an act of intervention attempting to change existing discourses, to name just a few. Which role did the translator who was focussed on completing

\footnotetext{
${ }^{1}$ Refer to James S. Holmes map of the discipline of Translation Studies with focus on time-restricted translation studies.
} 
a contract unleashing translatorial action (Holz-Mänttäri), to borrow a theoretical term coined for the world of professional translation, play? The translation, investigated from these aspects, ceases to be words strung together in a target language, following the source text faithfully or unfaithfully, instead it starts telling a tale of a bygone time, of the then reader, of the then skopos or function (Reiß/Vermeer) and of another world far removed from the present world.

This paper aims to carefully investigate the above questions and show that this bygone world can be re-created by analysing the translation along certain parameters like language, form and textual content. What needs to be clarified at the outset is, that the kind of translations which lend themselves to such investigations are necessarily translations that raise a question in the mind of a reader, who is familiar with translations of the Panchatantra texts as well as the original texts. They are translations that contain textual elements which I would like to call "stumbling blocks". This is the English translation of the German word "Stolpersteine". The term "stumbling blocks" sounds negative. One gets the impression that the textual elements spoken of, hamper the readability of the translation. If the reader refers to the meaning of the German word in the end note, the reader would be convinced of its aptness for the issue at hand ${ }^{2}$. What is meant by it follows. While reading such translations, the reader

${ }^{2}$ While using the term "stumbling blocks" I am actually literally translating the German word "Stolpersteine". These are small cubically shaped stones which are intentionally embedded into roads in Germany where Jews who were killed during Hitler Germany lived. These stones have the details of those Jews who lived on the said street and were victim of the genocide in Germany under Hitler engraved on them. The stone has on it details about the Jew like name, the date of birth etc. The idea is, when one perceives these stones while walking on the said street, one takes notice of the engraved information. This exercise forces one to remember the Jewish victims who lost their lives in Germany. Similarly, when one confronts peculiar textual elements in the translation, one is forced to take notice of them and thereby pay a kind of homage to the Translation activity of the said period. 
stumbles upon textual elements which the reader thinks. This happens because these textual elements, these "stumbling blocks" stand out of the textual landscape for today's reader (here, textual elements which stand out for today's reader because they belong to an earlier stage of language development, are excluded). They are textual elements in the target language text which differ from those in the source language text. like the difference in the register of the target language, the presence or absence of pre-suppositions, difference in the suprasegmental properties like printing of some textual features in bold or in italics (Nord: 163), additions and deletions, explicitation (Vinay/Darbelnet: 342) and implicitation (Vinay/Darbelnet: 344) to name just a few. These differences in the textual elements are so noticeable that the reader is forced to take notice of the text as a conscious creation by the translator. These differences result from the constraints and compulsions under which the translation was done. They have their roots in the socio-historical, geographical, cultural and most importantly, translatorial context of the target text. The translation initiator is one of the key players in the Pañchatantra translations. The translation initiator influences the translation brief, the translation function and lastly, the translation strategy, which is affected by all the previously mentioned parameters. It is these elements in the translation which tell a tale. These are the points of investigation which when completed; crystallize to create a picture of the culture. Just as important landmarks like the Gateway of India or India Gate in photographs help us locate and situate the picture in Mumbai or Delhi, so also these "fossilized" textual landmarks in a translation help us in locating and situating the translation in a particular geographical, historical, social, and cultural context. This paper seeks to reveal one such journey beginning with these fossilized textual elements of a translation along with all the 
information one has today about the translation. It ends with the description of a bygone world, in which the translation was created. In doing so the author hopes to humbly contribute to, what has been referred to by Holmes, as the field of "sociotranslation studies" (72).

\section{Overview of Important Pañchatantra Translations at Home and Abroad}

Following are mentioned, very briefly, facts about the Pañchatantra which are significant from the translation perspective. This is followed by a short note on the spread of the work through the medium of translations in and outside India. In this way the reader is prepared for the last section in this part of the paper, which introduces the reader to the Pañchatantra translations in medieval Marathi as well as the Marathi translation identified for the investigation.

\section{A-General Overview of the PañChatantra Translations within India}

The work Pañchatantra has been presumed to be in existence since the time period between 300 B.C. and 570 AD. It was written in Sanskrit by Chānakya. This original work has been long lost. The Panchatantra has been translated over and over again but there are eight texts which are considered crucial for the study of the work today and they are: The Tantrakhyāyik $\bar{a}$ which most scholars believe to be the oldest. Its home is Kashmir. Next is the north western Pañchatantra from which we have the Nepalese Pañchatantra, the southern Pañchatantra and the Hitopdeś. Another form of the Pañchatantra, known to us is Gunādhya's "Brhtkathä" in "Paishachi" or "Prakrut" language which has been lost. Two of the volumes of stories derived from Gunādhya's Brhtkath $\bar{a}$ that are extant are Kshemendra's Brhtkathāmanjari which was written around 1040 A.D. and Somadeva's Kathāsaritasāgar written between 1063 and 1082. It was between 850 and 1199 that a highly re- 
worked version of the Pañchatantra which had many additional stories was written. This was the work of an anonymous Jain monk. The work was titled Pañchākhyānaka and sub-titled Pañchatantra. It was from his manuscript that we have the Jain monk Purnabhadra's Pan̄chakhyānaka written around 1199 (Hertel: 19-20).

The Pañchatantra is a text which is a combination of verse and prose. Translations either are only in text form or a mixture of both. Metric translations of the Pañchatantra in Indian languages as well as foreign languages are also to be found.

What we find today as translations in almost all Indian languages, use, either one of the above-mentioned books or a combination of the above-mentioned sources. To cite an example the Hitopdeś has been widely translated into most European and Indian languages. In Indian languages it has been translated into Brij Bhakha, titled "Rajneeti" by Lallu Lal, into Hindi titled "Updes Darpan" by Badri Lalin 1851, in Marathi by Pandit Vaijnath, published in 1815, into Telugu in 1891, into Tamil etc. (Hertel: 30-69). The Pañchatantra has been translated in old Gujarati, new Gujarati, old Marathi, new Marathi and also in some dialects. These are just a few works mentioned here as it is impossible to mention the numerous translations in all Indian languages. Due to the sheer volume of the translation activity of the work in Indian languages and the lack of investigations and documentation in this regard, it is more difficult to plot the spread of this work in all Indian languages as compared to non-Indian languages, as will be evident from the following discussion.

\section{B- General Overview of the PañChatantra Translations Outside India}

It is easier to follow the spread of the Pañchatantra outside of India as compared to within India. The Pahlavi (old Persian) translation of the Pañchatantra by Burzuyeh, titled Kalilah wa 
Dimnah was the first translation in a foreign language commissioned by the Persian King Chosrau Anōsharwan in the $6^{\text {th }}$ century (Hertel: 362). It played a crucial role in spreading this work all over the world. Though this translation, along with a lot of other Persian literature was destroyed when the Arabs invaded Iran, it survived in the form of the Arabic translation by Abdallâh-ibn al-Muqaffa, an erstwhile Persian and follower of the Zoroastrian faith, who had converted to Islam. Muqaffa was employed by the state in Iraq as a court writer. He later incurred the wrath of the Kalif al-Mansûr for writing a mercy petition for someone the Kalif was against. So Muqaffa was tried and found guilty by the state. The injustice, with which Muqaffa met, influenced his translation of the Pañchatantra and he changed the ending of the first Tantra "Mitrabhed". This first Tantra or book of the Pañchatantra, as it is sometimes referred to in English, ends in the unjust death of the bull Sanjeevak caused by the crafty jackal Dumanak who wants to break the friendship of the lion King Pingalak and the bull Sanjeevak for personal gain. Muqaffa, who had himself been meted out injustice, changed the ending of the first book of the Pañchatantra by adding a last chapter in which Damanak who is responsible for breaking the friendship between the lion and the bull is put on trial and found guilty. In this way justice is restored in Muqaffa's translation. Muqaffa's translation spread to all Muslim countries and it is in this new form that the Pañchatantra spread in the occident (Geissler: 359). The Indian texts do not have this trial of Damanak whereas most old European translations which were done around the $15^{\text {th }}$ and $16^{\text {th }}$ century have it. The other translation of the Pañchatantra responsible for its spread in Europe is the Syrian version by Būd titled Kalilag and Damnag, which was translated from the Pahlavi around the $6^{\text {th }}$ century. Not many translations of this version are found in other languages. The Hebrew translation by Rabbi Joël at the beginning of the $12^{\text {th }}$ 
century and the Latin translation of the Hebrew text by John of Capua around 1270 are responsible for the spread of the work to other European languages.

Without going into too many details about the migration of this work within India and other foreign languages ${ }^{3}$ it suffices to say that the Pañchatantra is the most translated text in the world, next only to the Bible and the Communist Manifesto (Ruben: 5).

This brief overview, especially the part dealing with the Arabic translation by Muqaffa, reveals the ambiguity of the concept of an 'original' where the Pañchatantra translations are concerned, especially with regard to the form and the content. In some translations the sequence of the stories is changed, in some stories are dropped, in others they are added and very often one finds that the Pañchatantra which has also been known to be referred to as a 'secular Bible' (Jacobs: Intridcution xxxviii), excuse the oxymoron, becomes religious. None of these changes, in my opinion are arbitrary. Each adaptation, addition of a story, change in the end of the story has a reason which merits investigation. In this paper the author will investigate some of the changes found in the identified Marathi translation and seek the reasons for all these changes in the context in which the translation was done. Therein also lays, in my opinion, the strength of the engagement with this work, especially for Translation Studies.

\section{C-Development of the Marathi Language and the Early PañChatantra Translations}

One sees that there are, particularly in Marathi, innumerable translations of the Pañchatantra. If one studies the Pañchatantra

\footnotetext{
${ }^{3}$ Refer to Johannes Hertel's book Das Panchatantra seine Geschichte und seine Verbreitung for a detailed information on the various recensions and translations of the Pañchatantra
} 
translations in Marathi, one notices that they all can be classified into, what I would like to call, two waves of translation production. The first wave of translations of the Pañchatantra was done in the Medieval Age ${ }^{4}$ and the second wave was done in colonial India ${ }^{5}$. The former is of interest here as the translation identified for this paper belongs to the Medieval Age.

The activity of translation in the Marathi language in this first wave warrants a sneak peek into the development of the Marathi language itself and a brief summary of its movement from the fringes and periphery to the centre of the literary polysystem of those times (Itamar Even-Zohar).

Inscriptions show that the Marathi language must have originated in the $8^{\text {th }}$ century. Around 1281 when Jnaneshwari was composed it had already become a fully developed language which enjoyed prestige even in other regions (Pawar: 342f). The development of Marathi is believed to be as follows: At first it was Maharashtri then it developed into, what is known as, Mahāāashtri Apabhramsha from which it developed into Marathi (Bhave: 5; Pawar: 341). The

\footnotetext{
${ }^{4}$ The medieval age of Marathi literature begins in A.D. 1278 and ends in A.D. 1800.This time period spanning six centuries is divided into three periods: the first beginning at the end of the $13^{\text {th }}$ century and ending in 1350, the second extending from 1350 to 1650 . The third is between 1650 and 1800 . The second period is further divided into two periods: One from 1350 to 1500 and the other from 1500 to 1650 . The period from 1350 to 1600 is particularly of interest here as the investigated translation belongs to this period. It is a period that represents a" rather barren stretch from the point of view of literary compositions" (Pawar: 358).

${ }^{5}$ The Panchatantra translations done in colonial India are interesting too as they were done in a Marathi language dictated by the British Marathi experts. Anything and everything written in Marathi had to be approved by British editors. For more information on it please refer to Ranganathan, Murali (Ed.). (2009). Govind Narayan's Mumbai: An urban Biography from 1863.
} 
development of the bhasas and the linguistic consciousness by the people was a pan India phenomenon by the $11^{\text {th }}$ and the $12^{\text {th }}$ centuries (Pawar: 343). The first piece of literature produced in the Marathi language is supposed to be the work Viveksindhu by Mukundraj. He is supposed to be the first poet (period is 1120-1220) in early twelfth century (Bhave: 38; Pawar: 355). Lilācharitra is the first prose text in Marathi. It is a biography of Chakradhar Swami the founder of the Mahānubhāv sect (also known as Mahātma, Jaikrishna and Achyut). It was written in 1278 by his disciple Mhaimbhatt (Pawar: 346-347). The golden period of Marathi literature lasted till 1350. The language prospered under the royal patronage of the Yadava dynast Ramdevraya.

All the Marathi translations of the Panchatantra, done in the medieval ages are called Pañchopākhyāna (Kolte Introduction 7). Vinayak Laxman Bhave, researcher of old Marathi literature and responsible for writing the first ever historiography of the Marathi literature mentions, that till date, more than ten translations of the Pañchatantra have been located in Marathi, which are prose as well metric and they were all carried out between $12^{\text {th }}$ and $16^{\text {th }}$ century (36). Pawar mentions that some translations of the Pañchatantra were done between 1350 and 1680 (359) and Kolte mentions that the Pañchatantra had been translated much before the $16^{\text {th }}$ century (Introduction 7).

Five metric translations of the Pañchatantra are known to be in existence in the Marathi language. Let us have a look at the information on these five translations that is available to us.

The first translation is Nirmala Pathak's Pañchopākhyāna which is a metric version of the Pañchatantra written in the Ovimeter in 1529 (1450 shake). The second one is Mahalingadas Ahirrao's Pañchopākhyāna written in 1573 (1494 shake). Mahalingdas was an author who wrote on a 
variety of subjects ranging from folklore like Vetalpanchvishi and Sinhāsanbattisito books that had utility value for the common public like Shâlihotra, a book that gave information on horse care (Bhave: 309-310). The third translation known to us is Krishnaraj's Panchopakhyāna. The date of this translation production is not known. Going by the language used in it, Krishnaraj's Pañchopākhyāna must have been written some time after Mahalingadas's. Krishnaraj's narration of how the Pañchopakhyāna stories came to the Earth from the heavens tells us that he has used either Someshwar's Kathāsaritasāgar or Kshemendra's Brhtkathāmanjari as his sources. The fourth Pañchopakhyāna is one written by someone called Prahlad Bhaskar. It was written in 1695 (1616 shake). There also exists an anonymous translation which is estimated to be the youngest translation ${ }^{6}$ (Kolte Introduction: 25-44).

Two names which have figured above as translators find mention elsewhere as being the disciples of the Mahānubhā $v$ sect. They are Krishnaraj and Bhaskar. The Mahānubhāv sect was one of the important religious sects of the $12^{\text {th }}$ century. Krishnaraj, one of the disciples took the sect to the Punjab. His disciple was Prahlad Bhaskar (Bhave: 89). One can't help but wonder whether both these Mahānubhāvpanth disciples are the same ones who have also translated the Pañchopākhyāna which have been mentioned above. Then may be one could speak of the existence of a tradition of translating the Pañchatantra amongst the Mahānubhāvpanthis.

There are a few numbers of prose translations as well. Most of the manuscripts of these translations are in a bad condition. Some of them are either partially lost or preserved in libraries abroad. For instance, the entire work of Bhaskar's translation

\footnotetext{
${ }^{6}$ For more information on all these translations refer to Kolte Introduction: $25 \mathrm{ff}$
} 
is not in existence. What have remained are some pages of the beginning of the third book and the fifth book (Kolte Introduction 41).

\section{D- The Investigated "PañChopāKhyāNa"}

The translation that has been taken for investigation is an anonymous Marathi translation of the Pañchatantra called "Pañchopākhyāna". The texts which have been referred to for investigation are the fifth (Kolte: 16-22) and the seventh (Kolte: 24-25) stories of the first Book (Tantra) "Mitrabhed". The text has verse as well as prose sections.

This brings me to the end of the second part of the paper in which some important information on the work in general was given, the spread of the work in and outside India was discussed and the Marathi translations of the work along with the one being used for the purpose of this paper was introduced.

\section{The Investigation and Analysis of the Panchopākhyāna}

The third section of the paper has three parts. The first part will deal with identifying those textual elements which the author considers as "stumbling blocks", in other words, which make a reader who is familiar with the many versions of the Pañchatantra wonder and ask the question "why". Then the second part of this section of the paper will be devoted to a translation-based textual analysis of the target text based on the information contained in the introduction to the translation by the editor as well as the analysis of certain textual elements of the fifth and the seventh stories. The last part of this section will be dedicated to connecting the dots between the textual peculiarities and the then-prevalent culture, society, and political realities, thereby situating and locating the translation in its geo-politico-socio-cultural and translatorial context in order to investigate the 'fossilized culture' in the translation. 
Pañchopākhyāna: Fossilized Marathi Culture...

\section{A- The Stumbling Blocks}

Anybody who has read a few of the Marathi translations of the Pañchatantra, be they from the first wave or the second, is bound to ask the question "why translation is as it is" at certain places of the texts identified for investigation. Following are some such textual places marked for investigation.

The first observation one makes is, that the translation is highly abridged and simplified. What could possibly have been the reason for this shortened and over-simplified version?

The second textual place marked for investigation is the 'Kathāmukh'. All the Sanskrit texts of the Pañchatantra start with the "Kathāmukh" in which some deities, important individuals rivers, mountains etc. are invoked for protection and for salutation: Deities like Brahmā, Vishnu, Varun, Yamrāj etc. the four ages, Satya-, Tretā-, Dwāpār- and Kaliyug, important rivers, mountains, scholastic entities and seers like Manu, Śukra, Vācaspati,, Parāśara, Vyāsa, Chānakya etc. The number of the invoked deities and natural forces vary from version to version and become the first point of fruitful investigation. The 'Kathāmukh' of this anonymous translation only mention two deities Krishna and Dattātreya (Shri Krishnāyenmā, Shri Dattātreynmā: Kolte 1). What could have been the reason for mentioning only these two deities 'Krishna' and 'Dattātreya' in the 'Kathāmukh'?

The third "stumbling block" is, in my opinion, the biggest "stumbling block", because it is responsible for giving this translation its own unique character and that is the Marathi language used in this text. It not only merits a lot of attention but also reveals most about the historical, geographical, social and religious context of the translation. Let us examine the language in the fifth story of the translation, the story of the hermit Devsarman and the thief Ashādhbhuti. The reader frequently confronts non-Marathi words like 'jwab' (page 20 
line 24) ('answer'- my translation), 'dhapave' (page 20 line 24) from the Hindi 'dhakna' (to close - my translation), Sanskrit words like 'nāseek' (nose - my translation page 21 line 27) 'prajanyu' ('to rain' -my translation page 22 line 1) 'udak' ('water'- my translation page 20 line 2), 'kupa' ('well'- my translation page 26 line 25). So, on page 20 one finds words having Persian, Sanskrit and Hindi roots.

The fourth peculiarity is the use of two different words coming from two different languages for referring to one and the same thing, concept or idea e.g. 'parinayan' (page 30 line 21) and 'gāndharvavivāh' (page 30 line 18). Both the words mean marriage, the former is a Sanskrit one the latter a Marathi one.

This constant change in the language in the text from a classical language, like Sanskrit to the colloquial old Marathi, from the local Marathi to the Indian language Hindi and then again, the use of foreign words from Persian results in a constant change in the text. Why did the translation borrow so many words from foreign languages like Persian as well as Indian languages like Hindi and Sanskrit?

The fifth stumbling block is the use of extremely rough and coarse expressions, what we might today term as, street language, like the word 'rande' ('bitch' -my translation Page 20 line 27) for example.

The above is a sample of the kind of textual elements that are present throughout this translation. When the reader confronts elements like the above s/he wonders why the Kathāmukh has specific mention of only two deities, why the language is a potpourri of so many Indian and non-Indian languages other than Marathi and what could be the reason for the upward and downward scaling of the text by the use of Sanskrit and dialect respectively? The following analysis attempts to find the answers to the above questions. 


\section{B- Historical, Political, Social and Translatorial Context of the Translation}

The editor of the investigated translation Pañchopakhyāna has given some important information regarding the translation in the introduction to the translation which helps us in analysing the target text. Let us have a look at what we know about the text external factors based on this information. Kolte, the editor of the translation, is of the opinion that the text should be referred to as an adaptation (rupāntar) rather than a translation (bhāshāntar) because of the liberty the translator takes with the selective inclusion of certain shlokas while giving just a gist of some others by paraphrasing them. Often some verses are deleted, some are included. It is not a word for word translation (Introduction: 60ff). The translator, according to Kolte, knew Sanskrit but was not very well versed in it, as he has mistranslated in some places (Introduction: 62). Some fifteen Arabic and Persian words like miskin, jwab, firadi, bharosā, lajeemā, hisab, deewān, kharch etc. are found frequently in the translation. (Introduction: 70). The way the manuscript was tied and written, points clearly to the fact that it is a manuscript of the Mahānubhāv sect, a sect established in the $12^{\text {th }}$ century. The translation according to V. B. Kolte has been done in 1776. This 1776 manuscript has been copied from a much older translation done probably in the $14^{\text {th }}$ century. The reason to say so stems from the kind of words used the specific style of conjugating words as well as the plural and singular forms of the nouns. (Introduction: 70). The manuscript which was available to the editor was written in the Balbodh letters, but it has been copied from a manuscript which might have been written in the Sakal script, which was one of the many, the code scripts developed by the Mahānubhāv sect. There are inconsistencies in the manuscript which can be traced back to mistakes made by the disciple who copied the translation from the older Sakal script (Introduction: 
47-52). He is of the opinion that the Marathi into which the translation has been done belongs to the Yadava period (69f).

To sum up allow me to list our 'take-away- information' from this extremely valuable introduction. This translation was done in the $14^{\text {th }}$ century in Maharashtra under the Yadava dynasty by a Mahānubhāv disciple or follower.

Let us now begin discussing the external and the internal factors using Nord's model based on the information provided in the introduction. Those factors which remain unexplained will be speculated upon by situating and locating the translation in its historical, political, cultural, sociological and translatorial context in the last part of this section. It may be noted that the translation based textual analysis of only the target text is being undertaken here.

\section{C- Translation-Based Textual Analysis}

\section{Text- External Factors}

Sender- Since this is a Mahānubhāv text the sender, the commissioner of the translation has to have been a person of authority in the Mahānubhāv sect. The translator also has to have been from the same sect. That the translation is a translation by a Mahānubhāvpanthi throws light on other factors too.

Function- The function of the translation is to translate the Sanskrit work in a way that it becomes comprehensible to the reader (Kolte: Introduction 63).

Recipients- There is no information on the readers from the editor hence that is something we will have to find out by locating and situating the text in its geo-politico-socio-cultural context.

Time- Though there is a lot of time lapse between the older and the newer manuscripts, there is very little chance of 
changes in the two texts because changing the sect's texts was completely prohibited in this sect (Bhave: 78). So, we can safely assume the time of creation of the translation to be the $14^{\text {th }}$ century.

Place- The translation has been done in Maharashtra under the Yadava dynasty.

Medium- The medium is old Marathi and the text is a combination of verse and prose.

Motive- The motive for the translation is not mentioned anywhere in the introduction but based on the information on the sender, time and place the motive can be reconstructed by locating the translation in its geographical, historical and cultural context. The motive will not only answer why the translation was commissioned but will also reveal how it was supposed to be done. This will be discussed after a brief discussion on the internal factors because it is a question of connecting the dots, which is the last part of this section.

\section{Text - Internal Factors}

Subject Matter- The subject matter is the Pañchatantra, a work which consists of five books each one propagating a strategy on becoming successful.

Content- The content of the translation has been changed, the Kathāmukh being a case in point.

Text Composition- The target text is a highly abridged version of the source text.

Pre-Supposition- In the seventh story about the crane and the fishes there is a reference to the 'rohini' -constellation (Page 24, line 11f), which has not been explained. Hence it is presumed that the readers knew about Astronomy. The nonMarathi words also have not been explained so one can 
presume that the target reader was used to using a language which was a potpourri of many languages.

Function- The function of the translation will have to be extracted from its historical--politico-socio-cultural and translatorial context as it is not mentioned anywhere in the book.

Lexis- The language used is a mixture of Old Marathi, Marathi dialect, Persian, Arabic, braj bhāsha and Sanskrit words.

Sentence Structure- The sentence structure in the translation is another proof for the translation being written in the $14^{\text {th }}$ century. From the point of view of translation, the investigations of this factor do not yield us much.

Non-Verbal Elements- The translation made available by the editor does not sport any non-verbal elements. Most Pañchatantra translations, old and new, in Indian and foreign languages, have pictures depicting scenes from the stories but this particular translation does not have any pictures.

Supra-Segmental Elements ${ }^{7}$ - These are the use of varying font types, symbols, bold lettering, underlining etc., in short, any tool, stylistic features in a written literature which expresses the stress, rhythm and stylistic punctuation of a text. There are many translations of the Panchatantra which do not make a differentiation between the prose and the verse sections of the text while others like the one investigated here does. The verse is written separately in a different font so as to be visible as a verse and stand out from the rest of the text. This then is a strategy to draw attention, stress and emphasize the words of wisdom in the verse. It is widely known that the verses in Panchatantra were learnt by heart by school children because they were indeed words of wisdom. So, the translation

${ }^{7}$ These are described as stress, rhythm and stylistic punctuation. 
emphasizes them by setting them apart from the rest of the text. Hence it becomes a supra segmental feature.

This brings me to the end of the text-external and text-internal factors of the target text, as revealed by the information given in the introduction as well as an analysis of two stories of the investigated translation. Information on three factors, namely, reader, motive and function of the translation still need to be revealed. Attempt will be made to search for the information by situating the translation in its historical, political, social, cultural and translatorial context in the next section.

\section{D- Connecting the Dots - Situating the Translation}

In this part of this section attempt will be made to undertake a journey beginning with the peculiar textual elements in the translation and searching the reason for the same in the historical, political, socio-cultural and translatorial conditions. In order to situate and locate this translation one has help from information given by the editor and the "stumbling blocks" mentioned above as well. Let us first consider the information given by the editor.

The translation is supposed to have been done in the $14^{\text {th }}$ century in the Maharashtra under the Yadavas and it was done by a disciple of the Mahānubhāv sect. The translation is more of an adaptation done and has been done in a way that the Sanskrit text is made comprehensible. This information tells us a lot about the translation time -initiator, -function, - ideology, -receiver/reader, -strategy.

Crucial to our investigation is the time period when the translation was written, which is $14^{\text {th }}$ century. Let us attempt to understand the historical, social, political and cultural scene in the Maharashtra of the $14^{\text {th }}$ century.

$14^{\text {th }}$ century India was historically a period of perpetual flux. Life was complex and dynamic (Paniker: xxiii). The $14^{\text {th }}$ 
century is a century which is temporally situated on the cusp of change. It is a century in which there were tremendous political, social and religious changes in Maharashtra. It witnessed the golden age of the Yadava rule under which royal patronage to the Marathi language was at its highest, but also the fall of it, it witnessed the establishment of Muslim Kingdom after the invasion of Alauddin in 1318 (Pawar: 359) which later led to replacing Sanskrit and Kannada with Persian, Arabic and Turkish as court languages, it is also the century that witnessed the twelve-year divine drought from 1396-1408, which was the drought of Durgadevi (Pawar: 358), a period during which many people migrated out of Maharashtra to places as far off as the Konkan, Punjab and Tamil Nadu, returning to Maharashtra after twelve years, bringing with them words and expressions, stylistic features and the cultural elements of the culture they had migrated to (Bhave: 213-218).

This period, mainly the period between 1350 to 1500 , after the demise of the great saint poet Namdeva, and the challenges of a natural disaster changed not only the political but also the social and the linguistic make up of the Marathi language. Internal wars with the Muslims and the political instability along with destitute caused by the famine caused a break in the literary production. Some translations of the Pañchatantra were made during this period (Pawar: 359; Bhave: 36) but other than that there was no literary work of the quality of $13^{\text {th }}$ century works like Dnyaneshwari ${ }^{8}$. So, we can safely say that the Pañchatantra translations done between the time period

${ }^{8}$ P.L. Deshpande's book Marathi Vangmayacha Galiv Itihaas mentions that the $14^{\text {th }}$ century is marked by production of literature which was politically neutral. The kind of works produced were mainly books on the New Grammar rules, or some or the other guide, in short topics which would not incur the wrath of the reigning Kings. Refer to pages 32-33 for information on the same. 
1350 to 1500 , and there were at least three such translations, were done in a literary vacuum.

What do we know about the Mahānubhāv sect? It was established in the $13^{\text {th }}$ century (Pawar: 343 ) by Chakradhar Swāmi, who was a contemporary of Jnaneshawar. The Mahānubhāvpanthis are devotees of Krishna. This was a century of many sects like Nāth, Vārkari, Shānkar, Kanthadi, Jangamjogi, Vishnuswami, Vaishnav, Shākta, Gānpatya, Vitthal, Kalankamār gi and Mahānubhāvpanth. Many philosophical streams were taking root at the time and they were in competition with each other. Buddhism and Jainism had established themselves as alternatives to the caste ridden Hindu religion. Each of these sects was trying to win over the population as followers. They particularly tried to win over those people who were a-sanskrit-tadnya (my translation- men and women who did not know Sanskrit) (Bhave: 95; Pawar: 349). Because of their proximity to the Yadava rulers ${ }^{9}$, the Marathi language, which had never been the court language, and was always competing with Kannada and Sanskrit, gained a never-before status as the language of the people. Inscriptions which were earlier only in Sanskrit began to be written in Marathi as well. The credit for writing the first prose text in the Marathi language also goes to them. The mahānubhāvpanthis translated a lot of Sanskrit texts into Marathi for the masses. Many Brahmins were their disciples and hence they had a sound knowledge of Sanskrit (Pawar: 345). One could also say that the era of the establishment of the Mahānubhāvpanth was the era of translation. The Mahānubhāv sect spread right upto Kabul and the Punjab. Even in far off places like Kabul and the Punjab there was an

\footnotetext{
${ }^{9}$ The Mahanubhaav disciples enjoyed royal patronage. Not only did they manage to make inroads into the royal family but also win over some members of the royal family for their sect. For more information please refer to Bhave pages 79f.Pawar Page no. 345
} 
insistence on the use of Marathi (Pawar: 349). Marathi came to be spoken also by the Punjabi disciples because it was the language of their new faith. As a result, Punjabi words and expressions crept into the Marathi language. From Punjab the Marathi people brought Chess and along with the game came the words and phrases used in the game (Bhave: 216).

Mahānubhāv sect made use of Marathi so that women and the Shudras and common men in general could understand religion. These were those sections of society which had no knowledge of Sanskrit. If the Mahānubhāv sect too resorted to Sanskrit, then a large section of their followers would have been "deprived of religious thought" (Pawar: 349). Mahānubhāvpanthis did not believe in caste and gender discrimination, idol worship and untouchability. They believed in the vegetarian way of life (Bhave: 81-83). Hence though they were Hindus their practices set them apart from the non Mahānubhāv Hindus incurring the wrath of the Hindus. The Muslims were intolerant especially of faiths that practised idol worship. Since the Mahanubhaav sect did not believe in idol worship they were perceived to be non-Hindu by the Muslim rulers. In official correspondence (sanad) of the Muslims too the Mahanubaavpanthis were considered as non-Hindus. They were given concessions which the Hindus were denied like e.g. setting up their centres of worship 'ote' all over Maharashtra, they were exempted from a tax (jizya) levied by the Muslims on all non-Muslim faiths. This alienated the Mahānubhāvpanthis further from the other Hindus and caused friction amongst the Hindus and the Mahānubhāvpanthis (Bhave: 80). The followers of the sect were hounded and they developed a sense of insecurity which led them to develop some code scripts like sakali, sundar, pāramāndalya, subhadrā, anka, shree (Bhave: 77). They professed extreme renunciation and austerity, respect for other faiths, living off only the alms from the people. The Mahānubhāv sect as well as the Varkari 
sect insisted on the use of Marathi. Several religious and literary works were composed by the Mahānubhāvpanthis, thereby enriching the Marathi language (Pawar: 356). The only authority they believe in is Krishna and Dattatreya. The Mahanubhaav sect made use of Marathi so that women and Shudras, and common man in general could understand religion (Pawar: 349). In course of time a lot of things changed in this sect but those changes are not relevant to our present investigation $^{10}$.

What is our take-away from the above information and can it throw light on our understanding of the "stumbling blocks" in the investigated translation?

The first stumbling block mentioned above was, why the translation is a highly abridged and simplified version of the Pañchatantra? After situating the translation in its time and place it became clear that the Mahānubhāvpanth mainly wooed the women, shudras and the a-sanskrit-tadnya (people who did not know Sanskrit). Hence the translation had to be in tune with the readers who belonged to be above-mentioned class. That explains why a shorter version with mainly the basic information was preferred. If one refers to the Panchatantra texts which are considered as the "original versions" like the Tantrakhyāyik $\bar{a}$ or the south Indian Panchatantra, one finds that there are long passages with detailed information on what is considered as right by the scriptures. There are 16 shlokas in the beginning of the first frame story of the first Tantra, the story of Vardhamān in the city of Mahilāropya. In this story

\footnotetext{
${ }^{10}$ Later on code scripts were used making the books of this sect and the teachings of the sect itself inaccessible to the masses. In times to come idol worship too crept into this sect. Hence a sect which was responsible for promoting and creating a huge body of literature in Marathi disappeared from the collective memory of the very people it was started for. Refer to pages 63-94 for more detailed information on the Mahanubhavpanth sect.
} 
there are long discussions on the importance of earning money and being rich and then the elaboration on the 6 ways of earning money being: Collecting alms, serving the king, agriculture, imparting knowledge, money lending and lastly doing business. Then there is discussion on how the last option is the best way to earn a lot of money. Here the advantages and disadvantages of each mode of employment are discussed till the protagonist decides that doing business is the best mode of earning money. Then there is further classification of business types that he can do: He mentions seven different types of practices which will get him more money like 1) trading spices, perfumes; 2) money-lending against mortgaged jewellery; 3) simple money lending against additional interest; 4) selling to a group of people known to the seller i.e. wholesale of products; 5) selling products at false price; 6) fooling the buyer by weighing wrongly; and 7) travelling to distance places and buying that which is locally available there and bringing it back home to sell it at higher price at home. This entire discussion is compressed in 8 shlokas in the investigated translation. At times much fewer discussions are seen in the investigated translation. Wherever there are such discussions the investigated translation cuts short the discussion.

The second stumbling block was the mention of Krishna and Dattatreya in the Kathāmukh. Since the translator was a Mahānubhāvpanthi, the salutation had to be to the deities the Mahānubhāvpanthis believes in, that is Krishna.

The third stumbling block was the use of multiple languages. If the preferred language of communication for the Mahānubhāvpanthis was supposed to be Marathi then why the use of so many Sanskrit, Persian and Hindi words? The above discussion throws light on this phenomenon. Along with the Muslim domination came the compulsory use of Persian, 
especially in work place (Bhave: 218). Slowly some words made it to the language of the common people and became a part and parcel of the Marathi language. The reason for the assimilation of words and poetic meter (chhand) from the Brij Bhasha in Marathi can be found in the divine drought which triggered forced migration to distant lands. From these lands came the non-marathi words in the Marathi language.

The fourth stumbling block is the use of two different words coming from two different languages for referring to one and the same thing, concept or idea i.e. the use of Sanskrit and Marathi words for the same word. In the investigated translation the Sanskrit word for nose "nāsik"(21), "prajanya" for rain (22)"udak" for water (25)"parinayan" for marriage (30) along with "vivāh" in the same story are to be found. The entire translation sports many such Sanskrit words. As already mentioned above Sanskrit was the most important language. The work Pañchatantra was originally written in was Sanskrit. The translator wanted probably to gain legitimacy for the translation by showing that s/he was well versed in the language of the source text. Another reason could have been that the language spoken in those days must have been a mixture of Marathi and Sanskrit. A third reason can be found in the linguistically mixed population the translator was trying to address: Sanskrit-tadnyaand a-Sanskrit-tadnya people (people knowing and not knowing Sanskrit).

The fifth stumbling block is the use of very crass, street language giving the language a low register. In the first Tantra for example there is the story of the hermit and the thief Ashādbhuti in which such words are found. The fisherman in the story is angry with his wife who indulges in adultery and calls her "rānde" (20). In the story of the two friends of whom one falls in love with a princess, he tells his friend that he will survive only if he has sex with the princess. In the text it says 
"rajkkanyesi sambhogu hoye tarich pranu vache" This again could be because the milieu of the reader the translator was appealing to was the lower one which was known to use such language.

The analysis above addresses the 'stumbling blocks' in the investigated translation. Attention will now be turned to the three factors of translation-based text analysis, namely, reader, motive and intention, which could not be addressed based on the information above. Attempt will be made in the following to re-construct the period and connect the dots, so that the three factors are satisfactorily addressed.

Reader- It is very clear from the above that the translation was meant for ladies and people of lower castes who had no knowledge of Sanskrit. That explains why a simplified translation of the Pañchatantra was the aim for the translator. It also explains the use of dialect in the translation.

Motive- What was the motive to translate the Pañchatantra? The motive behind the selection of particularly the Pañchatantra can only be guessed at, as the investigator could not find any documentary proof on it. It must have been to add to the repertoire of the Mahānibhāv literature works which is accessible to common people thereby gaining followers for their sect. The idea also stems from a sense of competition with other sects and religions which were already in existence from the $12^{\text {th }}$ century like the Vaidik, Varkari, Shānka etc. (Bhave: 95), the rising influence of the Jain and the Buddhist religions and Islam. Moreover, a new language, new literature which is being established borrows heavily from canonical literature which is in the centre of the literary polysystem. Sanskrit was the language of the elite and the learned community of letters under the Yadavas. Hence one sees the Mahānubhāv sect taking from the literature of the very language it was in competition with, namely, Sanskrit, (Bhave: 
95) to build its literary repertoire as well as gain validity for itself by leaning on to an already established important Sanskrit work, namely the Pañchatantra.

The Pañchatantra is largely a secular work. I say so because apart from the Kathāmukh, in which there is a mention of the names of Gods, in no story are there any references to Gods. At no point in any story do the protagonists call upon the Gods to help them in their problem. Exceptions are two stories: In the story of the weaver who loved a princess in the first Tantra there is a mention of the Lord Vishnu and his vehicle the bird "Garuda" and the second story is the story of the plover who invokes Lord Vishnu in his fight against the sea which destroyed his eggs. In a book which has around 77 (the number varies from version to version) stories that all talk about how to win, fight, survive by using wit and intellect turning to God for help is found in only two stories.

The Panchatantra teaches the reader how a weakling positioned on the lower rungs of the societal ladder can challenge the authority of a strong competitor occupying the higher echelons of the community. There are many stories in the first Book which prove this point. Story of the crow and his wife who fight against a snake which eats all their newborns, story of a hare who manages to kill a lion by using his wit, story of a plover who fights the sea, Goraksh the house cleaning drudge who wins against an influential merchant Dantil and so on and so forth. The Panchatantra is all about strategies employed by the weak to fight the strong. This work embodies the basic tenets of the Mahānubhāv sect which believes in a class-less and equal society. In the Pañchatantra the word jatihas been used frequently but it refers to a group where the group members share some common qualities e.g. the jâti of the herbivorous animals against the carnivorous animals. Though the work does not talk of an equal society which the 
Mahanubhaavs propagated, it does show how the lower jâtican get the better of the higher, how the weaker animal like the sparrow, the hare, the plover who have to use their wit since they do not have the physical strength of the animals of the higher Jâti like the lion, the elephant. So, in a way it encourages the reader to focus on one's strengths and one's aim to succeed, and therein could lie the motive to select this work for translation.

Intention- The Mahānubhāv sect had a one-point programme; that of "community reach-out". Though the Panchatantra stories were already a part of the popular tradition one notices that the Mahānubhāv translator attempts to appropriate the text of the Panchatantra in order to suit the tenets of his own faith by erasing the mention of innumerable deities in the Kathāmukh which is seen in the Sanskrit texts, and mentioning only Lord Krishna in the Kathämukh. Naturally he chooses the language of the common man to reach out. Hence the intention was that maximum people are able to read and understand the translation. That is also the reason why almost all their literature has been written in the Marathi language (Bhave: 95). As already mentioned above, this translation seems to have been produced in some sort of literary vacuum caused by political upheaval and natural disasters. A break in literary production is, in my opinion, always a fertile ground for the activity of translation.

\section{Conclusion}

The paper concludes with a summary of how the 'fossilized culture' embedded in the anonymously translated Marathi Panchopakhyāna of the $14^{\text {th }}$ century helps the reader to recreate the historical, political, social, cultural and translatorial conditions under which it was translated and which in turn influenced its translation. The conclusion also throws light on the investigated translation as well as the activity of 
Translation in Marathi in the identified period A.D. 1350 to 1600. It is surprising to see just how much can be revealed by analysing the 'fossilized culture' in a translation.

Textual elements of the anonymous translation that was investigated were classified into five 'stumbling blocks'. By situating these aspects historically, geographically, socially culturally and translatorially answers to the questions put forward in the beginning were answered. Investigations revealed that the abridged and simplified nature of the investigated translation as well as the crass language used in it could be attributed to the intended reader, the a-sanskrit-tadnya (people not knowing Sanskrit) of the $14^{\text {th }}$ century, mainly the women and the Shudrasand in order to reach out to maximum people. The motive of translating the text was to create literature for the Mahānubhāv sect in a time when there existed a literary vacuum. The function of the translation was to make the Panchantantra stories accessible and comprehensible to ordinary folk. The translation was reader oriented hence the language of the translation is a potpourri of multiple languages reflecting the way people spoke at that time. The investigation of this textual aspect takes us down the historical journey of the change in the rule of the Maharashtra of the times, the twelve-year drought, and both incidents which influenced the Marathi language used in the translation. It also reflects the society of those times and the ideology of the translation initiator. The Translation initiator and translator were followers of the Mahānubhāvpanth ideology which believed in a society of equals in a largely caste-ridden society. The anonymous translator of the investigated translation was, in my opinion, not a mere decoder. He was a mediator and his act of translation was an interventionist act, attempting to translate in keeping with the tenets of the Mahānubhāv sect. The translator not only created a text but also tried to create a discourse. The 
act of translation hence comes across as a religious, social and an interventionist act. It was religious, because the translation was done to create a repertoire of texts for an established religion which had to compete with numerous other religions, faiths and ideological currents of the times, social, because the act of translation embodied in it an act of social justice; namely making hitherto inaccessible literature to the sub-altern of the society and interventionist because it sought to change the discourse of caste hegemony. The activity of translation was not only an act of intervention but also an act of negotiation which the Mahānubhāvpanthis were adept at, be it negotiating with the Yadava dynasts and winning over key people of the administration for the propagation of their faith or endearing themselves to their victors, the Muslim Kings and thereby strategizing for the survival of their faith. This quality of 'reaching-out' is also evident in the translation strategy used.

The Translation reflects a multilingual, multireligious society, which was a smouldering, if not a melting, pot. Translation was necessarily target reader oriented. The source text did not enjoy the status of the "holy original". With regard to the approach of the Translator to translation I am reminded of the term "anthropophagic, cannibalistic approach" (Arrojo). The source text was important only so far as its selection for translation goes. But then it was devoured, appropriated, adapted to communicate the message of the translation initiator. The intention of the translation is supremely important and everything else, most importantly the source text, is subservient to this most decisive factor.

With regard to the activity of Translation one could probably say that it was the only literary activity happening in this time. It was, as already pointed out, a not so fertile a period for literary production. This has been seen elsewhere as well, that lack of good literature always is compensated by translation 
from good literature. Activities of Translation and Adaptation must have occupied, in my opinion, a good position in the Marathi literary polysystem of the times because practically all the faiths were using translations of Sanskrit texts for winning followers. The translators seem to walk a tight rope between using the Sanskrit texts to gain legitimacy for their work and, in the same breath so to say, give instead their translations the stamp desired by their commissioners. The translations are in that sense very emancipatory. It appears that the activity of translation in the medieval period of the Marathi literature was undertaken for two reasons. Translation into Marathi was done with the dual aim of one, empowering the common man and two, out of love and pride for the Marathi language (Pawar: 349)

Translation and the use of the Marathi language was the positive and creative response to the then - prevalent decadence of the Hindu religion, which resulted in a flurry of creative activity in terms of creating a huge body of literature in the language of the people

To sum up, it was possible to reveal the 'fossilized culture' in a Marathi translation of the $14^{\text {th }}$ century called Panchopakhāana translated by an anonymous Translator. This could be done by identifying those textual elements in the translation which raised questions in the mind of the reader. The questions led to investigations. The information given by the editor on the translation manuscript helped in situating the translation in its political, historical and social context. The exercise of situating the translation threw light on the identified textual elements and both supplemented each other in re - creating the context of the translation. In this way the 'frozen culture' in a translation was instrumental in recreating the society of a bygone era. 
Priyada Sridhar Padhye

\section{References}

Bhave, V. L. 1914. Maharashtra Saraswat. Purvanisaha. Pune: Publisher.

DeshPANDE, P. L. 1994. Marathi Vangmayacha Galiv Itihaas. Bombay: Mauj Prakashan.

Even Zohar, ITAMAR. 1978. The Position of Translated Literature within the Literary Polysystem. In Papers in Historical Poetics, 21-27. Israel: University Publishing Projects.

GEISSLER, FRIEDMAR. 1962. Pantschatantra. Berlin: Ruetten \& Loening.

HERTEL, JOHANNES. 1914. Das Pancatantra seine Geschichteund seine Verbreitung. Leipzig und Berlin: Vlg. Von B. G. Teubner. Online: https://archive.org/details/daspancatantrase00hert.

Holmes, James, S. 1994. Translated! Papers on Literary Translation and Translation Studies. Amsterdam: Rodopi. HolZ-MÄNTTÄRI, JUSTA. 1984. Translatorisches Handeln. Theorie und Methode. Helsinki: Finnische Akademie der Wissenschaften.

Kolte, V. B. 1979. Panchopakhyana. Mumbai: Maharashtra Rajya Sahitya-Sanskriti Mandal.

NoRD, Christiane. 1991. Text Analysis in Translation: Theory, Methodology and Didactic Application of a Model for Translation - Oriented Text Analysis. Amsterdam / New York: Rodopi.

NORTH, ThOMAS. (trans.). 1570. The Fables of Bidpai. Edinburgh and London: Ballantyne Hanson \& Co. Online: https://warburg.sas.ac.uk/pdf/neh5070b2327739.pdf.

PAWAR, G. M. 1997. Medieval Marathi Literature. In Paniker, Aiyyappa, K. (ed.), Indian Literature: Surveys and Selections I. 341-383. New Delhi: Sahitya Akademi. 
Pañchopākhyāna: Fossilized Marathi Culture...

Ranganathan, Murali. (ed.). 2009. Govind Narayan's Mumbai: An Urban Biography from 1863. U.S.A.: Anthem Press.

REIß, KATHARINA; AND VERMEER, HANS. J. 1984. Grundlegung einer allgemeinen Translationstheorie. Tübingen: Max Niemeyer Verlag.

RUBEN, WALTER. 1959. Pañcatantra und sein Morallehre. Berlin: Akademie Verlag.

SNELl-HoRnBY, MARY. 2006. The Turns of Translation Studies: New Paradigms or Shifting Viewpoints. Amsterdam/Philadelphia: John Benjamins Publishing Company.

TOURY, GIDEON. 1995. Descriptive Translation Studies and Beyond. Amsterdam and Philadelphia: John Benjamins Publishing Company.

VINAY, JEAN-PAUL; AND JEAN DARBELNET. 1958. Stylistiquecomparée du français et de l'anglais. $2^{\text {nd }}$ ed. 1977. Paris: Didier - translation by Juan C. Sager, M.-J. Hamel: Jean-Paul Vinay, Jean Darbelnet (1995). Comparative Stylistics of French and English. Amsterdam/Philadelphia: John Benjamins Publishing Company. 